\title{
Trenger vi virkelig flere obduksjoner?
}

\author{
Frekvensen av ikke-rettslige obduksjoner er fallende. Fra patologer hevdes det at dette er \\ en farlig utvikling, og at økt obduksjonsfrekvens er nødvendig for å redusere kliniske feil. \\ I denne kronikken gjennomgås de viktigste argumentene for å øke obduksjonsfrekvensen, \\ og det konkluderes med at det ikke er grunn til å utføre flere ikke-rettslige obduksjoner.
}

\section{Anders Svare \\ anders.svare@hnt.no \\ Medisinsk avdeling \\ Sykehuset Namsos \\ 7800 Namsos}

Når man samtaler med kolleger, synes det å være en utbredt oppfatning at det utføres for få ikke-rettslige obduksjoner. Den samme holdningen uttrykkes som regel i Tidsskriftet (1). For det meste er det patologer som ytrer seg både her og ellers i det offentlige rom.

Det siste året er problemstillingen aktualisert i form av et brev fra Universitets- og høgskolerådet til de regionale helseforetakene, hvor det uttrykkes bekymring for den avtakende obduksjonsfrekvensen (2).

Det er korrekt at obduksjonsfrekvensen er avtakende. Mens det i 1985 ble utført ca. 9000 obduksjoner, var antallet i 2007 nede på ca. 4000 . I 2006 ble ca. $8 \%$ av alle døde obdusert (3). Internasjonalt er trenden den samme.

\section{Argumenter for øt obduksjonsfrekvens}

Jeg har inntrykk av at hovedargumentet blant kolleger for å øke obduksjonsfrekvensen er at obduksjoner vil avdekke ukjente sykdomsårsaker, for eksempel i forbindelse med plutselig død. Ikke bare den legen som behandlet pasienten, men også et større medisinsk miljø vil kunne lære av dette tilfellet. Lærdommen vil så komme fremtidige pasienter til gode. Et beslektet argument er at obduksjon må ses på som en slags «pasientrettighet» (2). Kanskje har den avdøde eller pårørende vært skeptisk til helsevesenets diagnose og behandling. En obduksjon vil kunne avdekke feildiagnostikk og feilbehandling. Da ingen leger ønsker å gjøre feil, vil dette også kunne være et incitament til bedre diagnostikk og behandling for leger som har ansvar for mennesker i kritisk sykdomsfase. Obduksjonene vil også kunne avdekke sykdommer av betydning for avdødes slekt, f.eks. arvelige lidelser.
Det fremføres imidlertid også andre argumenter for flere obduksjoner. De fleste er oppsummert i en kommentarartikkel i New England Journal of Medicine i 2008 (4):

- Patologer trenger regelmessig trening/ repetisjon for å vedlikeholde kunnskapene, og obduksjoner er viktige i opplæringen av medisinstudenter og vordende patologer

- Høy obduksjonsfrekvens kan korrigere feil i dødsmeldinger, og dermed bidra til at Dødsårsaksregisteret blir mer korrekt. Dødsårsaksregisteret er igjen viktig for forskning og som grunnlag for helsepolitikk

- Tidlig påvisning av epidemiske eller endemiske sykdommer (et aktuelt eksempel kunne være svineinfluensa)

- Overvåking av bivirkninger av nye medikamenter, apparater eller prosedyrer

\section{Gjennomgang av argumentene}

Mange tror altså at høy obduksjonsfrekvens vil føre til færre diagnostiske feil før døden. Finnes det vitenskapelig belegg for dette? Med henvisning til en systematisk oversiktsartikkel i JAMA gjentas det stadig at det er vist en omvendt sammenheng mellom høy obduksjonsfrekvens og antallet diagnostiske feil i klinisk virksomhet (5). Dette er for så vidt korrekt, men det viser selvsagt ingen årsakssammenheng mellom høy obduksjonsfrekvens og lavere antall diagnostiske feil. En mer naturlig tolking er at man ved å øke antall obduksjoner selvsagt obduserer flere med avklart dødsårsak, og færre hvor dødsårsaken har vært usikker. Det finnes ikke studier som viser kausal sammenheng mellom økt obduksjonsfrekvens og lavere forekomst av diagnostiske feil. Kritikere kan hevde at det motsatte heller ikke er bevist, nemlig at økt obduksjonsfrekvens ikke reduserer antall behandlingsfeil. Dette er også korrekt. Men saken er imidlertid at det allerede foreligger svært mange studier om hvilke diagnoser som overses i kritisk premortal sykdomsfase $(5,6)$. Bare oversiktsartikkelen i JAMA refererer 53 obduksjonsserier (5). Disse seriene dekker et vidt spekter, noen er generelle obduksjonsserier, mens andre er på selekterte populasjoner. Ikke uventet er for eksempel lungeemboli en diagnose som ofte overses. Er det ikke bedre at klinikere studerer og diskuterer slike studier, i stedet for å be om obduksjoner de ikke kan dokumentere læringseffekt av?

Når det gjelder obduksjonenes betydning for kunnskapservervelse og -vedlikehold for patologer bør den være uomtvistelig. Spesielt med tanke på å opprettholde god kvalitet på rettsmedisinske obduksjoner er dette av stor samfunnsmessig betydning. Når det gjelder studentundervisningen, vises det til at opplæring knyttet til obduksjoner er godt evaluert av medisinstudentene (2). Det avgjørende er imidlertid ikke studentenes preferanser, men den faktiske kunnskapen de erverver seg. Det er vel tvilsomt om de er bedre egnet til å behandle pasienter om de har deltatt på obduksjoner, enn om de har sett anatomiske preparater eller kunstige modeller som illustrerer tilstandene.

Hva så med «pasientens» og pårørendes rett til obduksjon? Man kan tenke seg situasjoner hvor pasient og/eller pårørende har vært kritisk til den medisinske diagnostikken og behandlingen, eller situasjoner hvor mennesker dør og sykdomsbildet er uavklart. I slike høve er det viktig at pårørende får informasjon om at obduksjon ofte kan gi tilleggsopplysninger. Ønsker så pårørende obduksjon, bør helsevesenet strekke seg langt for å imøtekomme dette.

\section{Registrering av dødsårsak}

Hva gjelder dødsårsaksstatistikken, er det ingen tvil om at det gjøres og vil bli gjort mange diagnostiske feil i klinisk virksomhet. Nevnte oversiktsartikkel i JAMA fant at obduksjon avdekket større (major) diagnostiske feil hos $23,5 \%$ av de obduserte og klasse I-feil (avgjørende diagnostiske feil i den kritiske sykdomsfasen) hos $9,0 \%$ (5). Imidlertid viser artikkelen at feildiagnostiseringen, korrigert for relevante kovariabler, er sterkt fallende. Det estimeres at for hvert tiår siden 1960-årene er 


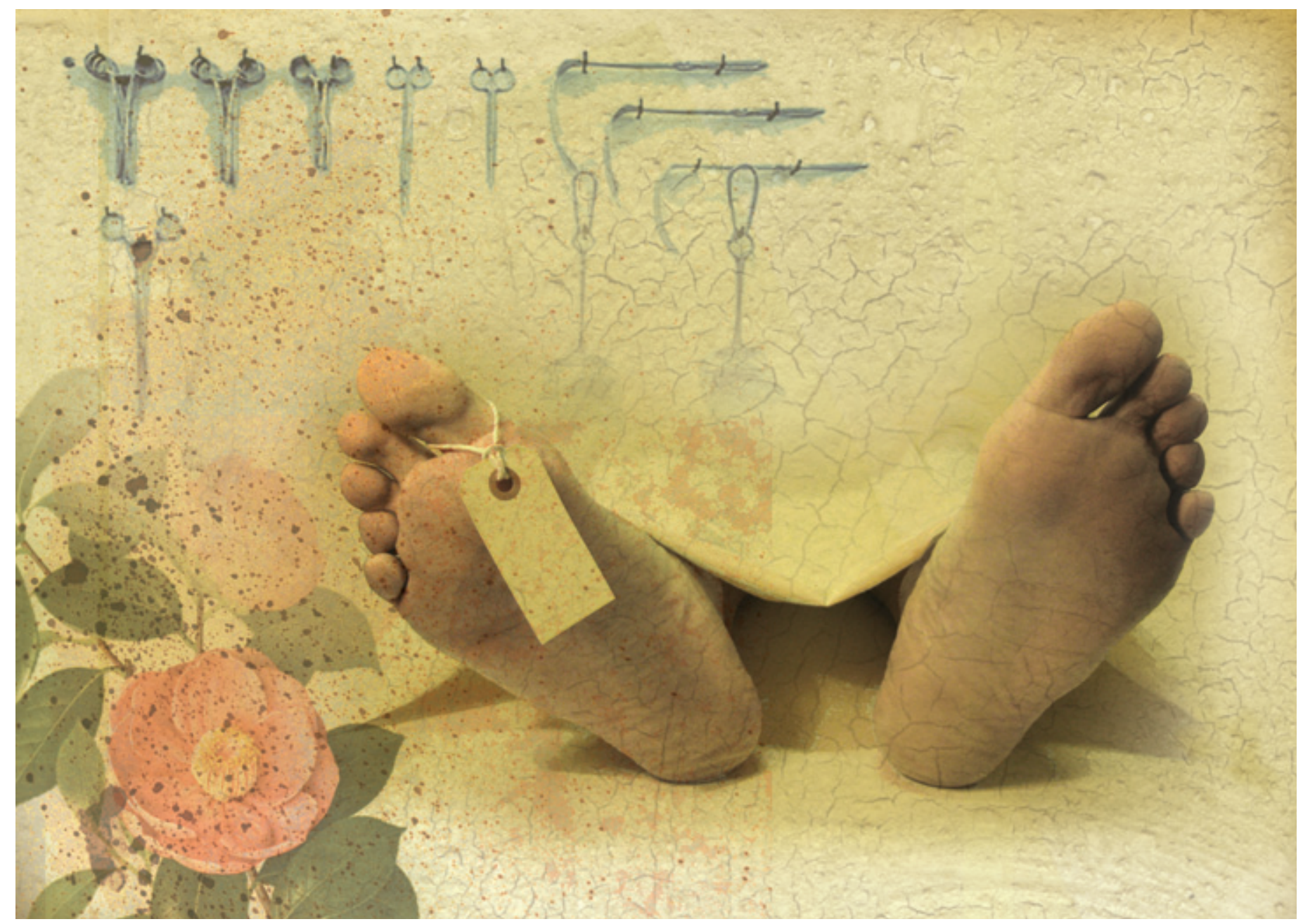

Illustrasjon Stein Løken

større diagnostiske feil redusert med 19,4\% og klasse I-feil med 33,4\%. Det er rimelig å tilskrive dette bedre diagnostikk, særlig radiologisk.

Det er viktig å presisere at obduksjon er et supplement til premortal diagnostikk, ikke en postmortal fasit. Ved diskrepans mellom pre- og postmortal diagnostikk kan det gjerne være den premortale diagnosen som er korrekt, slik en nylig (og nokså ubehagelig) kasuistikk i $B M J$ viser (7). Mange dødsårsaker vil ikke kunne påvises ved obduksjon, for eksempel hjertearytmier. I en relativt ny studie fra New York på kreftpasienter døde på intensivavdeling, fant man ved obduksjon ingen umiddelbar dødsårsak hos $17 \%$ (6). I og med at flere mennesker i dag behandles på intensivenheter $\mathrm{i}$ terminalfasen, og der gis behandling som utsetter dem for komplikasjoner det kan være vanskelig å diagnostisere (som opportunistiske infeksjoner), er det rimelig å tro at man i fremtiden vil få en økning av tilfeller der dødsårsaken også ved obduksjon forblir usikker. Ved obduksjoner er det vist høy korrelasjon (Cohens kappa 0,83-0,97) mellom de diagnoser ulike patologer setter som underliggende dødsårsak, mens det er vist større sprik i det som settes som umiddelbar årsak til døden (Cohens kappa 0,43-0,75) (8). Også etter obduksjon kan det altså hefte betydelig usikkerhet om dødsårsak.

Det er nok likevel et faktum at økt obduksjonsfrekvens, totalt sett, vil redusere antallet feil i Dødsårsaksregisteret. Men hvor viktig er egentlig dette? Det ligger i sakens natur at dødsårsaksregistre alltid vil inneholde mange feil. I en travel klinisk hverdag er utfylling av dødsmeldinger bare en av en lang rekke oppgaver det er ønskelig at man prioriterer. Blant annet har det kommet og kommer stadig flere andre registre (f.eks. hjerteinfarkt- og bruddregistre). Min egen erfaring er at utfylling av dødsmeldinger i praksis ofte nedprioriteres, og at det ofte er uerfarne leger som blir satt til å fylle dem ut. En annen fallgruve er at den døde kan ha mange sykdommer, og at det kan være vanskelig å avgjøre hvilke man skal ta med på dødsmeldingen. Selve logistikken på dødsmeldingen, med inndeling i umiddelbar, bakenforliggende og medvirkende årsaker til døden, kan være vanskelig å forstå og anvende på det enkelte tilfellet. Ofte vil også den legen som foretar utfyllingen, for eksempel en tilfeldig legevaktlege, ha begrenset kunnskap om avdødes sykehistorie. Studier har da også vist at det gjøres mye feil i utfyllingen av dødsmeldinger. I en nylig publisert studie på døde pasienter med diabetesdiagnose, ble diabetesdiagnosen kun nevnt på dødsmeldingen hos $34,7 \%$ (9). Obduksjon er et kostbart korrektiv til den antatte kliniske dødsårsaken. Hva er hensikten med å flikke litt på dødsårsaksstatistikken ved å øke obduksjonsfrekvensen, når statistikken i utgangspunktet likevel vil være så mangelfull?

\section{Konklusjon}

Det er ingen tvil om at de rettslige obduksjonene er av stor samfunnsnytte. Men når det gjelder de ikke-rettslige obduksjonene, skal det etter min mening foreligge en meget god grunn til å skjære i døde mennesker. Samfunnsnytten bør være uomtvistelig. Av de argumentene jeg har nevnt, er det for det første patologenes behov for å utvikle og vedlikeholde kunnskapene som fyller dette kravet. Videre bør obduksjon tilstrebes hvis pasient eller pårørende har uttrykt mistillit til diagnostikk eller behandling, eller etter pårørendes ønske ved uavklarte dødsfall. I tråd med moderne samfunnsutvikling kom det i 2004 en helt nød- 
vendig lovjustering av obduksjonspraksis, som sikret pårørende informasjons- og reservasjonsrett. Det er selvsagt vanskelig å estimere kostnadene knyttet til en obduksjon, men i amerikansk litteratur er de samfunnsmessige kostnadene angitt til 2 000-5 000 dollar (10). I en situasjon med konstant ressursknapphet i helsevesenet, er det å fremme en økt obduksjonsfrekvens feil vei å gå.

Oppgitte interessekonflikter: Ingen

\section{Litteratur}

1. Søreide K, Ellingsen CL. Obduksjon - kvalitetssikring i siste ledd. Tidsskr Nor Lægeforen 2007; 127: 2799

2. Solberg S. Lav obduksjonsfrekvens. Vet ikke hva folk dør av? Overlegen 2009, nr. 2: 7.

3. Den norske legeforening. www.legeforeningen.no/ asset/42142/1/42142 1.ppt [2.9. 2009].

4. Shojania KG, Burton EC. The vanishing nonforensic autopsy. N Engl J Med 2008; 358: 873-4.

5. Shojania KG, Burton EC, McDonald KM et al. Changes in rates of autopsy-detected diagnostic errors over time. JAMA 2003; 289: 2849-56.

6. Pastores SM, Dulu A, Voigt $L$ et al. Premortem clinical diagnosis and postmortem autopsy findings: discrepancies in critically ill cancer patients. Crit Care 2007; 11: R48.

7. Reisner $\mathrm{C}$. What are coroners and pathologists for? BMJ 2009; 338: 835

8. Veress B, Gadaleanu V, Nennesmo I et al. The reliability of autopsy diagnostics: inter-observer variation between pathologists, a preliminary report Qual Assur Health Care 1993. 5. 333-7.

9. Cheng WS, Wingard DL, Kritz-Silverstein D et al. Sensitivity and specificity of death certificates for diabetes. Diabetes Care 2008; 31: 279-84.

10. Xiao J, Krueger GR, Buja LM et al. The impact of declinig clinical autopsy: need for revised healthcare policy. Am J Med Sci 2009; 337: 41-46.

Manuskriptet ble mottatt 30.9. 2009 og godkjent

7.1. 2010. Medisinsk redaktør Are Brean. 